\title{
Agrobacterium-mediated transformation of Guignardia citricarpa: An efficient tool to gene transfer and random mutagenesis
}

\author{
Maria Beatriz Calderan RODRIGUES ${ }^{a, *}$, Léia Cecília de Lima FÁVARO ${ }^{b}$, \\ Ana Paula de Souza PALLU ${ }^{a}$, Anderson FERREIRA ${ }^{c}$, \\ Fernanda de Souza SEBASTIANES ${ }^{a}$, Maria Juliana Calderan RODRIGUES ${ }^{a}$, \\ Marcel Bellato SPÓSITO ${ }^{a}$, Welington Luiz DE ARAÚJO ${ }^{d}$, \\ Aline Aparecida PIZZIRANI-KLEINER ${ }^{a}$ \\ 'Universidade de São Paulo, Escola Superior de Agricultura 'Luiz de Queiroz', Departamento de Genética, \\ Laboratório de Genética de Microrganismos 'Prof. Dr João Lúcio de Azevedo', Av. Pádua Dias, 11, Caixa Postal 83, \\ CEP: 13400-970 Piracicaba, SP, Brazil \\ ${ }^{\mathrm{b}}$ Embrapa Agroenergia, Laboratório de Biologia Energética, Parque Estação Biológica S/N, \\ Avenida W3 Norte (final), CEP: 70.770-901 Brasília, DF, Brazil \\ ${ }^{\circ}$ Embrapa Agrossilvipastoril, área de P\&D, Avenida das Itaúbas, 3257, Setor Comercial, CEP: 78550-194 Sinop, \\ MT, Brazil \\ ${ }^{d}$ Laboratory of Molecular Biology and Microbial Ecology, NIB, University of Mogi das Cruzes, Av. Cândido Xavier \\ de Almeida Souza, 200, CEP: 08780-911 Mogi das Cruzes, SP, Brazil
}

\section{A R T I C L E I N F O}

Article history:

Received 27 May 2011

Received in revised form

24 May 2013

Accepted 19 June 2013

Available online 1 July 2013

Corresponding Editor:

Nina Gunde-Cimerman

\section{Keywords:}

Agrobacterium-mediated transfor-

\section{mation}

Citrus Black Spot

Genetic transformation

Guignardia citricarpa

Plant-pathogen interaction

\section{A B S T R A C T}

Guignardia citricarpa is the causal agent of Citrus Black Spot (CBS), an important disease in Citriculture. Due to the expressive value of this activity worldwide, especially in Brazil, understanding more about the functioning of this fungus is of utmost relevance, making possible the elucidation of its infection mechanisms, and providing tools to control CBS. This work describes for the first time an efficient and successful methodology for genetic transformation of G. citricarpa mycelia, which generated transformants expressing the gene encoding for the $\mathrm{gfp}$ (green fluorescent protein) and also their interaction with citrus plant. Mycelia of G. citricarpa were transformed via Agrobacterium tumefaciens, which carried the plasmid pFAT-gfp, contains the genes for hygromycin resistance ( $h p h$ ) as well as $g f p$. The optimization of the agrotransformation protocol was performed testing different conditions (type of membrane; inductor agent concentration [acetosyringone - AS] and cocultivation time). Results demonstrated that the best condition occurred with the utilization of cellulose's ester membrane; $200 \mu \mathrm{M}$ of AS and $96 \mathrm{~h}$ as cocultivation time. High mitotic stability ( $82 \%$ ) was displayed by transformants using Polymerase Chain Reaction (PCR) technique to confirm the $h p h$ gene insertion. In addition, the presence of gfp was observed inside mycelia by epifluorescence optical microscopy. This technique easy visualization of the behaviour of the pathogen interacting with the plant for the first time, allowing future

\footnotetext{
* Corresponding author. Tel.: +55 1992172678.

E-mail addresses: biacalderan@yahoo.com.br, beatrizcalderan@gmail.com (M. B. C. Rodrigues), leiacecilia@yahoo.com.br (L. C. L. Fávaro), apspallu@terra.com.br (A. P. S. Pallu), anderson.ferreira@embrapa.br (A. Ferreira), ferlss@gmail.com (F. S. Sebastianes), majulianaruxa@yahoo.com.br (M. J. C. Rodrigues), mbsposito@usp.br (M. B. Spósito), wlaraujo@usp.br (W. L. de Araújo), aline.kleiner@ usp.br (A. A. Pizzirani-Kleiner).

1878-6146/\$ - see front matter @ 2013 The British Mycological Society. Published by Elsevier Ltd. All rights reserved. http://dx.doi.org/10.1016/j.funbio.2013.06.005
} 
studies on the pathogenesis of this fungus. The establishment of a transformation method for $G$. citricarpa opens a range of possibilities and facilitates the study of insertional mutagenesis and genetic knockouts, in order to identify the most important genes involved in the pathogenesis mechanisms and plant-pathogen interaction.

(c) 2013 The British Mycological Society. Published by Elsevier Ltd. All rights reserved.

\section{Introduction}

Guignardia citricarpa Kiely (anamorph: Phyllosticta citricarpa McAlpine), an Ascomycete fungus, is the causal agent of Citrus Black Spot (CBS) disease in citrus plants. The most important symptoms caused by this disease are lesions on the rind of citrus fruits, which cause no internal decay (Kotzé 1981; Snowdon 1990; Smith et al. 1997), but fruits are depreciated in the fresh fruit market. Also, during fruit development, heavy infection close to the pedicel may induce premature fruit drop (Kotzé 1981; Smith et al. 1997) resulting in serious productivity losses.

Besides Brazil, the disease is present in countries like Argentina, Peru, Uruguay, South Africa, Mozambique, Kenya, Zambia, Zimbabwe, Japan, China, Hong Kong, Indonesia, Philippines, Taiwan, Australia, New Zealand (EPPO 2006), and recently, was reported at the United States of America (Adaskaveg et al. 2010; Schubert et al. 2010). This report was also investigated and confirmed by the Department of Agriculture of the United States (Adaskaveg et al. 2010). This disease has not been reported in North America thus far, marking a major spread of this pathogen in geographical context (Smith 2006).

At the European Union (EU), CBS is classified as A1 quarantine disease, which means that is not present in its member countries. Aiming to prevent the introduction of pathogens, they have a strong regulation that restricts the importation of citrus (Bonants et al. 2003). Detection of CBS disease in a single fruit prevents the landing of the good ones.

At CBS epidemic phase, G. citricarpa produces sexual and asexual spores. Pseudothecia along with ascospores are produced exclusively in decomposing leaves on the orchard floor (McOnie 1965; Kotzé 1981). Ascospores are released during rainfall events and are dispersed by wind. On the leaf surfaces in the presence of free water, ascospores infect the host by direct penetration and form a mycelial mass in the subcuticular region. The fungus then remains quiescent until the leaves fall or the fruit begins to ripen (Kotzé 2000).

Pycnidia with conidia are produced in hard spot and freckle spot fruit lesions as well as on dead branches and leaf litter prior to pseudothecia formation. When the pycnidia are mature, the conidia emerge from their ostiole covered by a mucilaginous substance and, in contact with water conidia are dispersed by splashing or being washed off by rain to nearby susceptible tissues, where new infections may occur (Kotzé 2000).

The underlying molecular mechanisms responsible for the complex symptomology have not yet been studied for $G$. citricarpa. Identification of plant infection and pathogenesis genes will enable us to address the key virulence aspects for this fungus and provide a foundation for better strategies to manage CBS. Analysis of gene functions can be accomplished via random mutagenesis or reverse genetic approaches. In this way, fungal transformation with heterologous DNA may result in random integration of the new genes into the fungal genome causing gene disruption as an insertional mutagenesis. The most important advantage of insertional mutagenesis over chemical or radiation mutagenesis is that the disrupted genes are tagged by the transforming DNA ( $\mathrm{T}$ DNA), which can be used to identify the disrupted genes (Sugui et al. 2005). Although classical genetic studies, such as parasexual and sexual recombination, had not been developed for $G$. citricarpa, functional genes related to plant infection, colonization, and pathogenesis can be identified through gene disruption by Agrobacterium tumefaciens-mediated transformation (ATMT), allowing the identification of genes related to these functions.

Many pathogenic fungi species and oomycetes have been already genetically transformated by this technique (Michielse et al. 2005; Lacroix et al. 2006). These results allow the study of the pathogenic behaviour of these fungi, such as the interaction with the plant, facilitating the comprehension of the pathogenic system, and the searching for control methods of disease. The plant-fungus interaction can also be studied by different approaches by microscopy techniques using reporter genes such as gene for green fluorescent protein ( $g f p$ ) of the jellyfish Aequorea victoria (Lorang et al. 2001). The ATMT allow this kind of insertion as tool of study, and has been widely used for gene transfer and as a tool for insertional mutagenesis (Abdudeh et al. 2000; Blaise et al. 2007).

Michielse et al. (2005) describe different factors as determinants of processing efficiency, among them, the strain of Agrobacterium, concentration of acetosyringone (AS), conditions for cocultivation, and substrate composition.

Here we report the transformation of $G$. citricarpa mediated by A. tumefaciens for insertional mutagenesis, gene disruption. Also, we used a gfp tagged strain to study fruit colonization, showing that this is an important strategy to understand the pathogenesis of this fungus in citrus plants.

In this work, our major aims were:

1. To develop and optimise protocol for transformation of G. citricarpa

2. Evaluate transformation efficiency at different conditions of:

a. Filter type

b. Concentration of AS - bacterial virulence inductor agent

c. Cocultivation period

3. To study the ability of G. citricarpa transformants to colonize the tissues of citrus fruit by microscopy technique

4. To check transformants for their infectiveness

5. To analyse enzymatic production modifications in transformants 


\section{Materials and methods}

\section{Strains, plasmids, and culture conditions}

Guignardia citricarpa strain 12P strain was previously isolated from Citrus sinensis 'Valência' (Rodrigues et al. 2007). This strain and transformants obtained by ATMT were grown on potato-dextrose-agar (PDA, Oxoid) at $28^{\circ} \mathrm{C}$, for $15 \mathrm{~d}$, and this collection is permanently conserved by Castellani method (Castellani 1963) at the 'Laboratório de Genética de Microrganismos Prof. Dr João Lúcio de Azevedo', University of São Paulo, Escola Superior de Agricultura 'Luiz de Queiroz', Department of Genetics, Piracicaba, São Paulo, Brazil. Agrobacterium tumefaciens strain EHA105 (kindly provided by Prof. Dr Carlos Alberto Labate - USP/ESALQ, Brazil) was grown in YEP (Chilton et al. 1974) supplemented with rifampicin $\left(100 \mu \mathrm{g} \mathrm{mL}^{-1}\right)$ and spectinomycin $\left(200 \mu \mathrm{g} \mathrm{mL} \mathrm{m}^{-1}\right)$. Transformants were selected on PDA medium supplemented with hygromycin $\left(75 \mu \mathrm{g} \mathrm{mL} \mathrm{m}^{-1}\right)$, sodium cefoxitin $\left(\right.$ Claforan $^{\circledR}$ ) $\left(300 \mu \mathrm{g} \mathrm{mL}^{-1}\right)$, and tetracyclin $\left(125 \mu \mathrm{g} \mathrm{mL}^{-1}\right)$.

The transformation vector pFAT-gfp (Fitzerland et al. 2003) was kindly provided by Dr M. Kim Plummer (CSIRO Plant Industry, Australia). This vector contains in the T-DNA region, the hygromycin resistance gene from Escherichia coli (hph), under control of the gpd (glyceraldehyde-3-phosphate dehydrogenase) gene promoter of Glomerella cingulata, as well as the gfp gene (pGreen Lantern, Life Technologies), controlled by gpd promoter from Aspergillus nidulans.

\section{ATMT transformation}

The electrocompetent EHA105 strain of Agrobacterium tumefaciens was prepared according to Lacorte \& Romano (1998) and transformed with pFAT-gfp vector. This transformed strain was grown on YEP broth in a rotatory shaker (180 rpm) at $28^{\circ} \mathrm{C}$ for $24 \mathrm{~h}$ until obtaining an OD $600 \mathrm{~nm}$ of 0.8 and transformation was carried out in according to De Groot et al. (1998). Fungal cultures actively growing on filter paper on a PDA plate were transferred with the filter to IM medium $\left(10 \mathrm{mM} \mathrm{K}_{2} \mathrm{HPO}_{4}\right.$; $10 \mathrm{mM} \mathrm{KH}_{2} \mathrm{PO}_{4} ; 2.5 \mathrm{mM} \mathrm{NaCl} ; 2 \mathrm{mM} \mathrm{MgSO}_{4} ; 0.7 \mathrm{mM} \mathrm{CaCl}_{2} ; 9 \mu \mathrm{M}$ $\mathrm{FeSO}_{4} ; 4 \mathrm{mM} \mathrm{NH}_{4} \mathrm{SO}_{4} ; 10 \mathrm{mM}$ glicose; $0.5 \%$ glicerol; $40 \mathrm{mM}$ acid 2-[N-morfolin]-ethanosulfonic esterillized by filtration, $\mathrm{pH}$ $5,3)$, plus the bacterial inductor of virulence agent AS (Fluka), tested in concentrations of 200 and $400 \mu \mathrm{M}$; and covered with $2 \mathrm{~mL}$ of an induced A. tumefaciens EAH105 [pFAT-gfp] culture. The plates were incubated at $28{ }^{\circ} \mathrm{C}$ for 48 and $96 \mathrm{~h}$ for cocultivation. To select the ATMT transformants, filters containing the transformants were transferred to selection plates and grown for $60 \mathrm{~d}$. Hygromycin-resistant colonies were subcultured onto PDA + HygB for five selective rounds. Different materials of filters to test the ability of the fungi to grown in it were observed. The filters used were cellulose's ester (Millipore $\left.{ }^{\circledR}\right)$; cellulose (J. Prolab, Brazil); and nylon (Amersham Hybond $\mathrm{N}^{+}$or GE Healthcare).

\section{DNA analysis}

The total DNA from wild type strain and transformants was extracted by a standard phenol-chloroform protocol according to Raeder \& Broda (1985). To analyse the number of T-DNA copies integrated in Guignardia citricarpa genome, three randomly selected transformants were evaluated by Southern blot (Fig 2). Fifteen grams of genomic DNA from the wild type strain and the transformants, and $2 \mathrm{~g}$ of vector DNA pFAT-gfp, were digested with EcoRI restriction enzyme, according to the manufacturer's recommendations (Invitrogen, Brazil). These DNA were cleaved with restriction enzyme EcoRI, which cuts the T-DNA two times and do not cut inside the gfp gene, and transferred to nylon membranes and hybridized with a probe fragment of $700 \mathrm{bp}$ of $g f p$ gene. The T-DNA region of the pFAT-gfp vector has two recognition sites for this endonuclease, both located in the gene expression cassette for resistance to hygromycin B (Fitzerland et al. 2003). Thus, when the hph gene is used as a probe, all transformants as well as vector gfp-pFAT, will present a band of $1600 \mathrm{bp}$, and one or more bands of different sizes, depending on the number of T-DNA insertions. The digested DNA was separated on $1 \%$ agarose gel and the standard procedures described by Sambrook \& Russell (2001) were used to transfer the gel to nylon membrane $\left(0.45 \mu \mathrm{m}\right.$, Amersham Hybond $\mathrm{N}^{+}$, GE Healthcare). The hph gene used as the probe was amplified from the vector pFAT-gfp with the primers hph1 and hph2, and purified with UltraClean ${ }^{\text {TM }}$ Polymerase Chain Reaction (PCR) Clean-Up Kit (MOBIO Laboratories). The probe labelling and hybridization were performed using the thermostable alkaline phosphatase system (Amersham AlkPhos Direct ${ }^{\mathrm{TM}}$ Labeling and Detection Systems, GE Healthcare), under conditions of high stringency $\left(60^{\circ} \mathrm{C}\right)$, according to the manufacturer's recommendations.

\section{Analysis of T-DNA flanking sequences}

The regions flanking the T-DNA insertion were identified by TAIL-PCR technique (Thermal Asymmetric Interlaced Polymerase Chain Reaction) (Liu \& Whittier 1995). For this, we used specific primers for left border (LB) and right border of the T-DNA vector pFAT-gfp (Fitzerland et al. 2003). The primers LB1-1 (5'-gtcagctccggcaccttatccttg- $\left.3^{\prime}\right)$, LB2-2 $\quad\left(5^{\prime}-\right.$ cctcgttacatcagctcgcagctac-3'), LB3-1 (5'-cgtccgcaatgtgttattaagttgtc- $\left.3^{\prime}\right)$, and RB1 (5'-aagatgggcagtctttcagaaggg- $\left.3^{\prime}\right)$, RB2-2 $\left(5^{\prime}\right.$-atcgcaaagtgaagtcttgctgcc- $\left.3^{\prime}\right)$, and RB3-2 (5'-ccaaacgtaaaacggcttgtcccgc- $3^{\prime}$ ) were used with arbitrary and degenerated (AD) primers. Specific primers for LB used in second and third reactions (LB2-2 and LB3-1, respectively) were placed at a distance of $105 \mathrm{bp}$ from each other, to facilitate the confirmation of product specificity by comparing the size of bands generated.

Genomic DNA of transformants was extracted according to Raeder \& Broda (1985) and used as template in the TAIL-PCR reactions. The $\mathrm{AD}$ primers (AD1, $\mathrm{AD} 2$, and $\mathrm{AD} 3$ ) used and the composition of the PCR reactions were those described by Liu \& Whittier (1995). The TAIL-PCR amplification was performed following the conditions published by Mullins \& Kang (2001). Amplification reactions were performed in a thermocycler PTC - 200 (MJ Research). For each transformant, the products generated in the first, second, and third reactions were analysed side by side on a $1.2 \%$ agarose gel. All fragments obtained from the third reaction showed that decrease in length consistent with the position of the primers in the T-DNA (compared to 
secondary reaction products) was considered as the junctions of T-DNA (Combier et al. 2003).

The products of the third reactions were purified from agarose gel, cloned into pGEM-T Easy vector (Promega, Brazil), and transformed into competent Escherichia coli DH5 $\alpha$ cells. The amplification of the insert was performed by colony PCR using M13 universal primers. PCR products were purified (UltraClean ${ }^{\mathrm{TM}}$ PCR Clean-Up Kit, MOBI Laboratories) and sequenced at the Center for Human Genome Studies, São Paulo, Brazil. Subsequently, the region corresponding to the T-DNA was removed and the remaining flanking sequences were analysed with the BLAST tool (blastx, searching protein database using a translated nucleotide query) against the GenBank database (http://www.ncbi.nlm.nih.gov/BLAST/). The sequences were also analysed for the presence of ORFs (Open Reading Frame) using the ORF Finder tool (http:// www.ncbi.nlm.nih.gov/), aiming to identify all ORFs using the standard or alternative genetic codes.

\section{Analysis of transformants by fluorescence microscopy (MOF)}

Transformants were randomly picked up and analysed for expression of the $g f p$ gene, using fluorescence microscopy. For visualization of fluorescence in conidia, transformants were cultured at $28{ }^{\circ} \mathrm{C}$ for $15-25 \mathrm{~d}$ on PDA medium (containing $75 \mu \mathrm{g} \mathrm{mL}{ }^{-1}$ hygromycin B). The CBS symptoms were cut with sterile scalpel and placed under sterile blades. The slides were prepared with sterile distilled water, sealed with colourless nail polish and directly analysed under a microscope. Analyses were performed using an epifluorescent microscope (Zeiss Axiophot-2) with a filter suitable for analysis of gfp. The samples were excited using a light with $490 \mathrm{~nm}$ wavelengths and the images were captured with a video camera attached to the microscope, using the ISIS software (Meta Systems, Germany). Inoculation of spores of Guignardia mangiferae, endophytic specie which has no ability to induce CBS symptoms, was used as a negative control (Fig 5C).

\section{Mitotic stability of transformants}

To determine the mitotic stability of the transformants, transformants were successively cultured on PDA without hygromycin B for ten generations, by subculture of hyphal tip and mycelium observation under epifluorescence microscope. Stable transformants were those which, after five successive passages in PDA medium, were able to grow on PDA amended with a concentration of hygromycin B previously determinate to this fungus, and retained the gfp fluorescence. Growth of Guignardia citricarpa 12P was successfully inhibited on PDA medium amended with hygromycin $B\left(50 \mu \mathrm{g} \mathrm{mL}^{-1}\right)$, allowing the use of this antibiotic as a selective marker. Here we used a selective culture media containing $75 \mu \mathrm{g} \mathrm{mL}{ }^{-1}$ hygromycin $\mathrm{B}$, to give more reliability of the experiment.

\section{Interaction between Guignardia citricarpa and citrus fruit}

Aiming to study the ability of G. citricarpa transformants to colonize the tissues of citrus fruit, we used microscopic analysis. This analysis was conducted with both the wild type strain and transformed strain expressing gfp.
First of all, spores of G. citricarpa wild type and transformants were obtained (Fig 1). Leaves of oranges trees (Citrus sinensis 'Valência') were detached, washed, and cut in small fragments of $1 \mathrm{~cm}^{2}$ and autoclaved. Eight fragments per plate were placed on the agar $3 \%$ medium. Mycelia of G. citricarpa were inoculated adjacent to the leaves' fragments (Fig 1A). The plates were cultivated at room temperature $\left(25^{\circ} \mathrm{C}\right)$ with $12 \mathrm{~h}$ of photoperiod for $21 \mathrm{~d}$. These asexual spores were inoculated in injuries done at the orange fruits by a sterilized stick and covered by moist cotton. The fruits were stored in a moist chamber (a box with humidity conditions, at room temperature) by $15 \mathrm{~d}$ until the symptoms appeared. The symptoms on fruits (black spots) were cut and placed on sterilized glass slides. The slides were prepared with sterile distilled water, sealed with colourless nail polish, and directly analysed under a microscope.

\section{Physiological characterization of Guignardia citricarpa transformants}

Aiming to check if the genetic insertion affected the ability of enzymes production of transformants, 15 randomly transformants were tested for their capacity to produce hydrolytic enzymes on solid medium (Hankin \& Anagnostakis 1975). The enzymes analysed were protease, lipase, esterase, and pectinase.

\section{Results}

\section{ATMT of Guignardia citricarpa}

The results showed that $G$. citricarpa transformants were obtained in all ATMT evaluated conditions (Table 1). We observed that the better transformation efficiency condition (greater number of transformants per experiment) was obtained at $96 \mathrm{~h}$ for $\mathrm{G}$. citricarpa-Agrobacterium tumefaciens cocultivation on a medium containing $200 \mathrm{mM}$ AS, and a cellulose ester membrane (Millipore, $0.45 \mu \mathrm{m}$ in porosity).

A solid substrate allows $G$. citricarpa and A. tumefaciens to grow close each other, so that the T-DNA may be transferred. We used three filter types as substrate and we observed that cellulose ester filter condition was better, showing larger number of transformants - 37 from 86 total; in the other hand, nylon filter showed a lower amount of transformants - 26 from 86 (Table 1). Although the presence of AS during A. tumefaciens-G. citricarpa cocultivation was imperative for transformation, the inclusion of $200 \mu \mathrm{M} \mathrm{mL}^{-1}$ generated 49 transformants per test, while $400 \mu \mathrm{M} \mathrm{mL}^{-1}$ resulted in $25 \%$ less transformants. Transformation efficiency increased consistently as the cocultivation period increased, resulting in twofold more transformants when cocultivation time was extended from $48 \mathrm{~h}$ to $96 \mathrm{~h}$ at $28^{\circ} \mathrm{C}$ (Table 1$)$.

Fig 4 shows the appearance of transformation signs $60 \mathrm{~d}$ after transferring the membranes to selective medium containing hygromycin $\mathrm{B}$.

The mitotic stability results show that $82 \%$ of the transformants retained the phenotype of resistance to hygromycin $B$ and expressed the gfp.

For Southern blotting analysis, the results showed that one transformant harboured a single copy of T-DNA integrated 

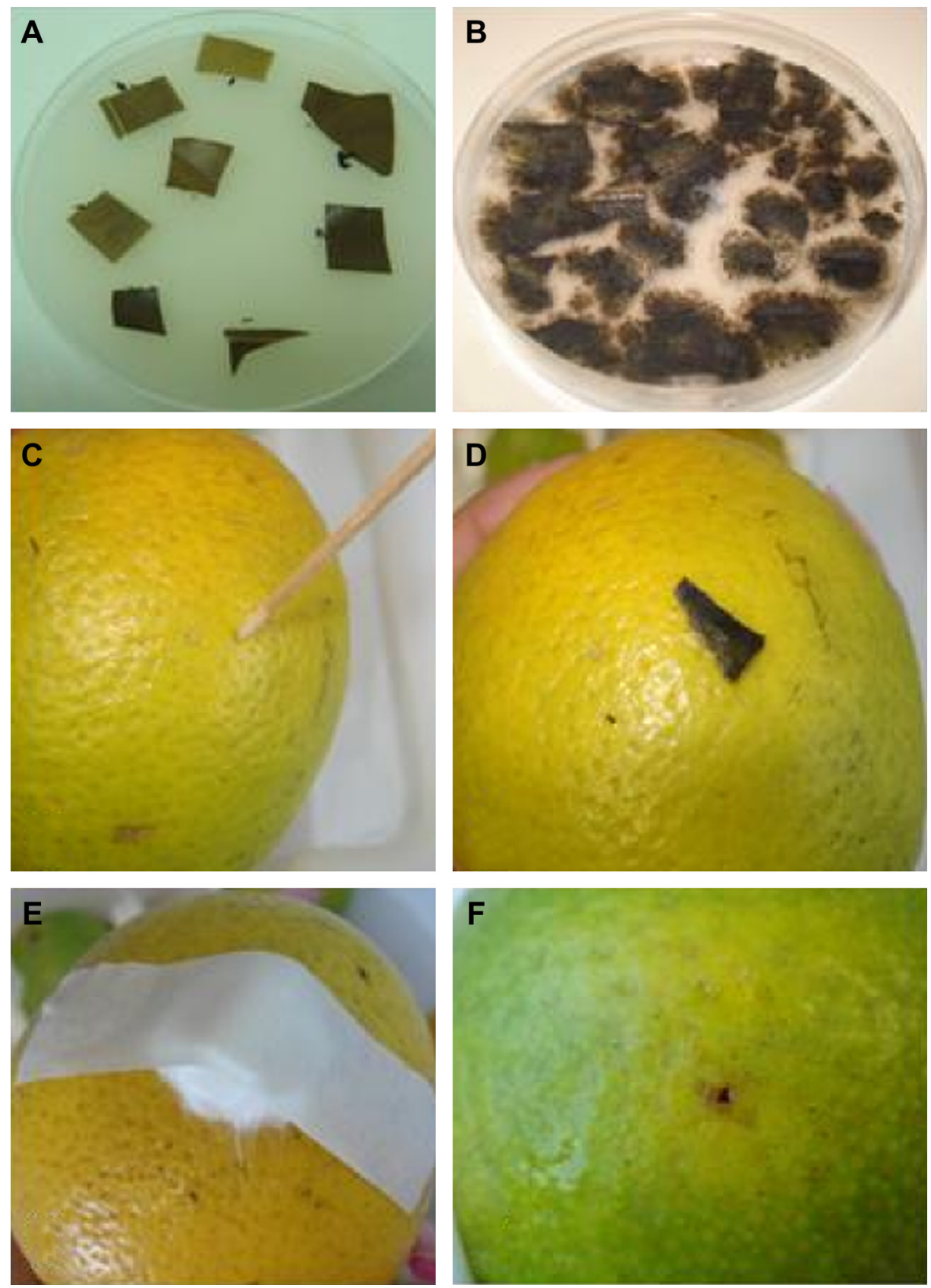

Fig 1 - Methodology used to obtain Guignardia citricarpa spores and bioassay on citrus fruits. (A, B): Production of G. citricarpa spores on orange leaves in a petri dish, after $21 \mathrm{~d}(\mathrm{~B})$; (C-E): mode of inoculation to perform the pathogenicity bioassay; (F): characteristic symptom of CBS on citrus fruits $15 \mathrm{~d}$ after the inoculation. (For interpretation of the references to colour in this figure legend, the reader is referred to the web version of this article.)

randomly in the host genome (Fig 2, L5). Also, two other analysed transformants presented two, three or more insertions (Fig 2 L3 and 4) in the genome.

\section{Analysis of T-DNA flanking sequences}

TAIL-PCR was used to identify the genomic DNA flanking the T-DNA insertion site (Liu \& Whittier 1995). Using random and specific primers, and three amplification rounds, we successfully amplified the junction DNA of eight transformants. The LB sequences obtained by TAIL-PCR generally ranged from 200 to $300 \mathrm{bp}$. ORF were identified by BLAST tools. Among the eight T-DNA insertions analysed in these mutants, five were identified as the pFAT-gfp vector, and three were ORFs showed high homology ( $\mathrm{E} \leq 1 \mathrm{e}-65$ ) to hypothetical fungal proteins with unknown function. However, using BLAST match $(E \leq 1 e-5)$ in the National Center for Biotechnology Information (NCBI) nonredundant (nr) protein database, the sequences were 
Table 1 - Guignardia citricarpa genetic transformation efficiency under various parameters tested: membrane type; concentration of AS; cocultivation time.

\begin{tabular}{llc} 
Parameter & Condition & $\begin{array}{c}\text { Number of transformants } \\
\text { in 20 plates }\end{array}$ \\
\hline Membrane & Cellulose ester & 37 \\
& Paper filter & 33 \\
& Nylon & 26 \\
Concentration & 200 & 49 \\
of AS $\left(\mu \mathrm{M} \mathrm{mL}^{-1}\right)$ & 400 & 37 \\
Cocultivation & 48 & 30 \\
time $(\mathrm{h})$ & 96 & 56 \\
Total & & 86 \\
\hline
\end{tabular}

similar to adenylyl sulphate reductase (CAP03145.1) of Pseudomonas sp. (Gama-proteobacteria), methyl-coenzyme $\mathrm{M}$ reductase (CBF64720.1) of Sclerolinum contortum (Annelida: Polychaeta), and N-acetylglucosaminyl-transferase (CAD90583.1) of Bradyrhizobium sp. (Alpha-proteobacteria).

\section{GFP expression and characterization of ATMT transformants}

Guignardia citricarpa mycelium was targeted with gfp gene under the control of the gpd promoter from Aspergillus nidulans. Following ATMT, 12 independent transformants were selected

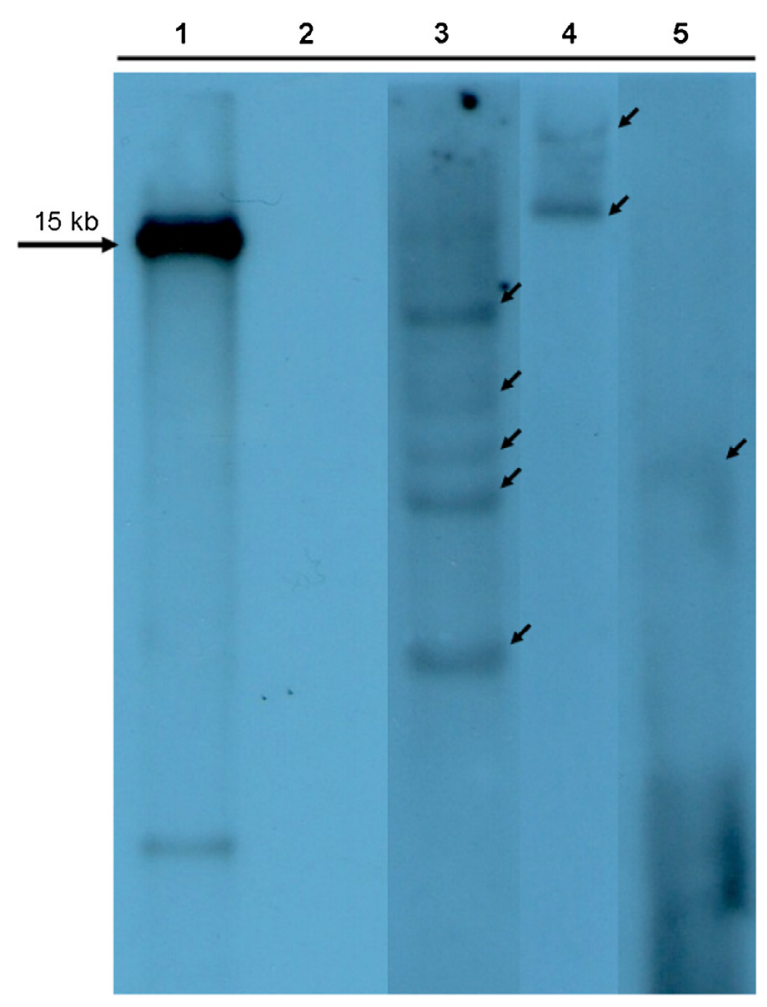

Fig 2 - Southern blot hybridization of three Guignardia citricarpa transformants and of $G$. citricarpa wild type 12P. Line 1 contains the vector pFAT-gfp (positive control); line 2 shows the wild type 12P G. citricarpa (negative control); lines 3-5 show the transformed isolates, chosen randomly. Arrows indicate the visualized bands. for further analysis. All transformants were subcultured for five generations in PDA + HygB selective and nonselective medium, where all transformants displayed normal growth and were mitotically stable. Epifluorescence analysis showed that, as expected, the wild type G. citricarpa did not show any fluorescence under the excitation and detection conditions. All evaluated transformants exhibited diffuse cellular gfp localization, although punctuated hyphae fluorescence was also observed, suggesting the presence of protein aggregates or vacuolar accumulation of gfp (Fig 3). Additionally, green fluorescence was sometimes attenuated by, probably, dark pigments of $\mathrm{G}$. citricarpa.

\section{Guignardia citricarpa-citrus interaction}

Spores of G. citricarpa wild 12P and transformants were inoculated on citrus fruits gave typical CBS symptoms. The injury caused by the fungi was characterized by round spots when skin becomes reddish (Fig 6) until finally becomes black. Transformant spores were inoculated on fruits and typical symptoms we observed (Fig 6). The behaviour of some 12P:gfp transformants was monitored by MOF during fruit infection (Fig 7). This is the first time that results using gfp were observed in G. citricarpa, showing the behaviour of the fungus. A dense hyphal mass involving mainly the intercellular spaces of the first layers of epidermal cells of plant tissue was observed (Fig 7).

All inoculated transformants induced typical CBS symptoms. The negative control, Guignardia mangiferae, showed no ability to induce CBS symptoms (Fig 5C).

Overall, the results (Fig 7) showed that the fungus colonized the fruit surface, forming a dense mycelial mass around the epidermal cells (Fig 7G-J). Furthermore, the analysis of cross sections revealed that all transformants of $G$. citricarpa were able to penetrate the host tissue and colonize the intercellular space of the first layers of the fruit peel epidermis (Fig 7K).

Moreover, the mycelial mass of transformants emits an intense green fluorescence (Fig 7I), allowing observation of fungal colonization over the plant tissue surface. It appears that first, the fungus colonizes the intercellular spaces of plant tissue (Fig 7J), starting with some body penetration, which is the early stage in the cell penetration (Fig 7K).

\section{Physiological characterization of Guignardia citricarpa transformants}

All G. citricarpa transformants (144) exhibited no morphophysiological (growth rate, colony morphology, and colour) changes when compared to wild type on PDA medium at $28^{\circ} \mathrm{C}$ (Fig 4D and F). For physiological analysis, 15 transformants were tested for their capacity to produce hydrolytic enzymes on solid medium. The secretion of protease, lipase, and esterase did not differ between the wild type strain and the transformants (results not shown).

However, for pectinases production, it was observed significant differences between the wild type and some transformants (Fig 5). From 15 random transformants evaluated, five were similar to wild type $12 \mathrm{P}$, while ten produced significantly lower amounts of pectinase. 

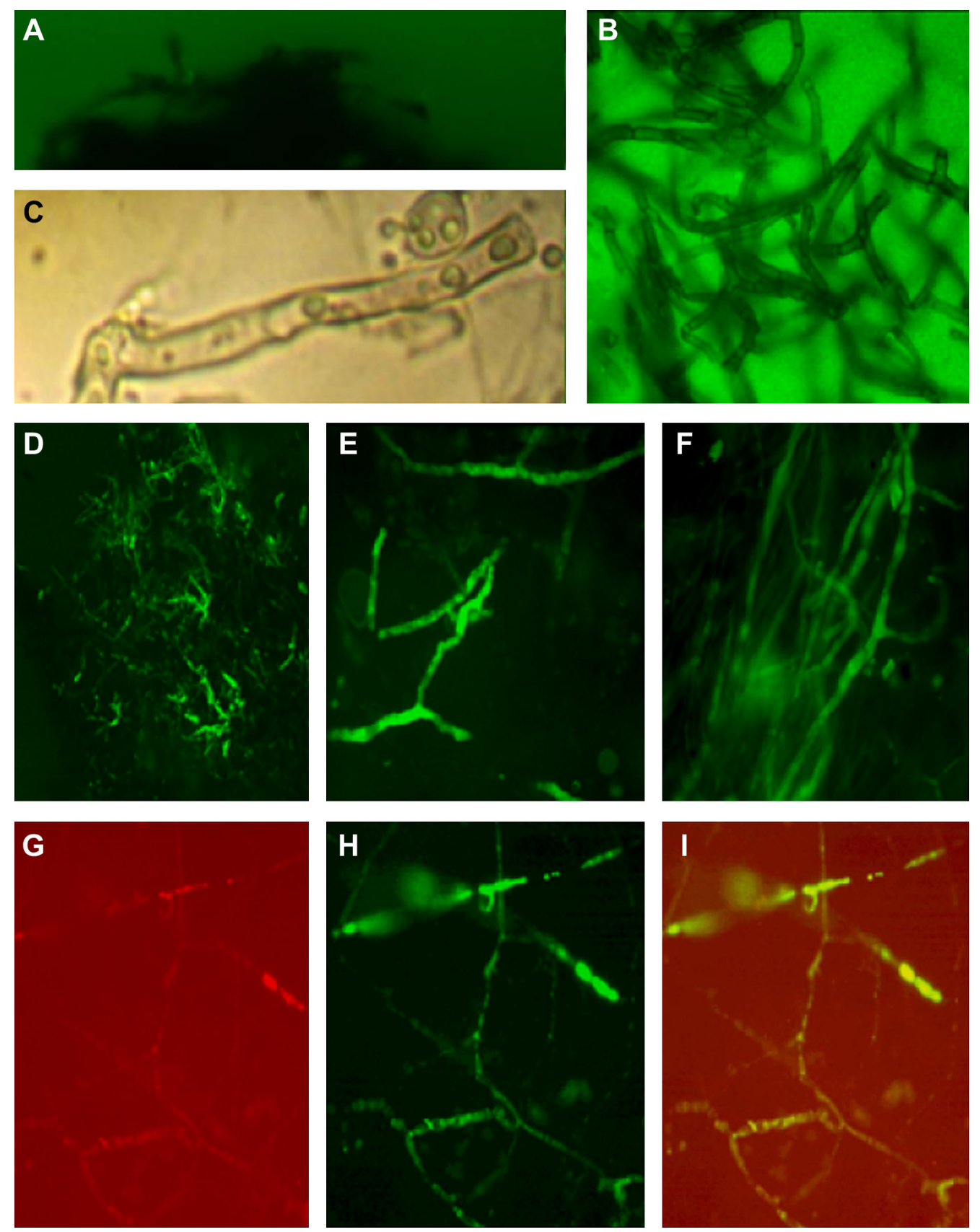

Fig 3 - The microscopic visualization of insertion of the gene for GFP from pFAT-gfp vector into the genome of Guignardia citricarpa transformants by epifluorescence optical microscopy. (A) Negative control, wild type 12P, mycelium without fluorescence $(200 \times)$, (B) negative control, wild type 12P, hyphae without fluorescence $(400 \times)$, (C) wild type 12P under optical microscope appearance of hyphae $(400 \times)(D, E)$ G. citricarpa transformant mycelium exhibiting fluorescence (D: $100 \times, \mathrm{E}$ : $400 \times$ ), (F) G. citricarpa transformant grown in liquid medium with mycelia showing fluorescence in liquid medium (400 $\times$ ), (G-I) G. citricarpa transformant under different types of light filters: red (G) and green (H) and with the overlay of both. (For interpretation of the references to colour in this figure legend, the reader is referred to the web version of this article.)

\section{Discussion}

Based on previous reports of Agrobacterium-mediated transformation in fungal species (Mullins \& Kang 2001; Sugui et al. 2005; Figueiredo et al. 2010), we adapted and optimized an ATMT system for gene transfer and random mutagenesis in Guignardia citricarpa, by using $h p h$ and $g f p$ genes as the selectable and reporter markers, respectively. Moreover, this is the first time that results using gfp as gene reporter were observed in G. citricarpa transformants, allowing to observe the behaviour of the fungus growing pattern in the epidermis of the citrus fruits.

According to our data, the best ATMT conditions for random insertion of T-DNA in G. citricarpa genome were obtained with mycelium-Agrobacterium tumefaciens cocultivation for $96 \mathrm{~h}$ on cellulose ester as filter (Millipore, $0.45 \mu \mathrm{m}$ in porosity) 


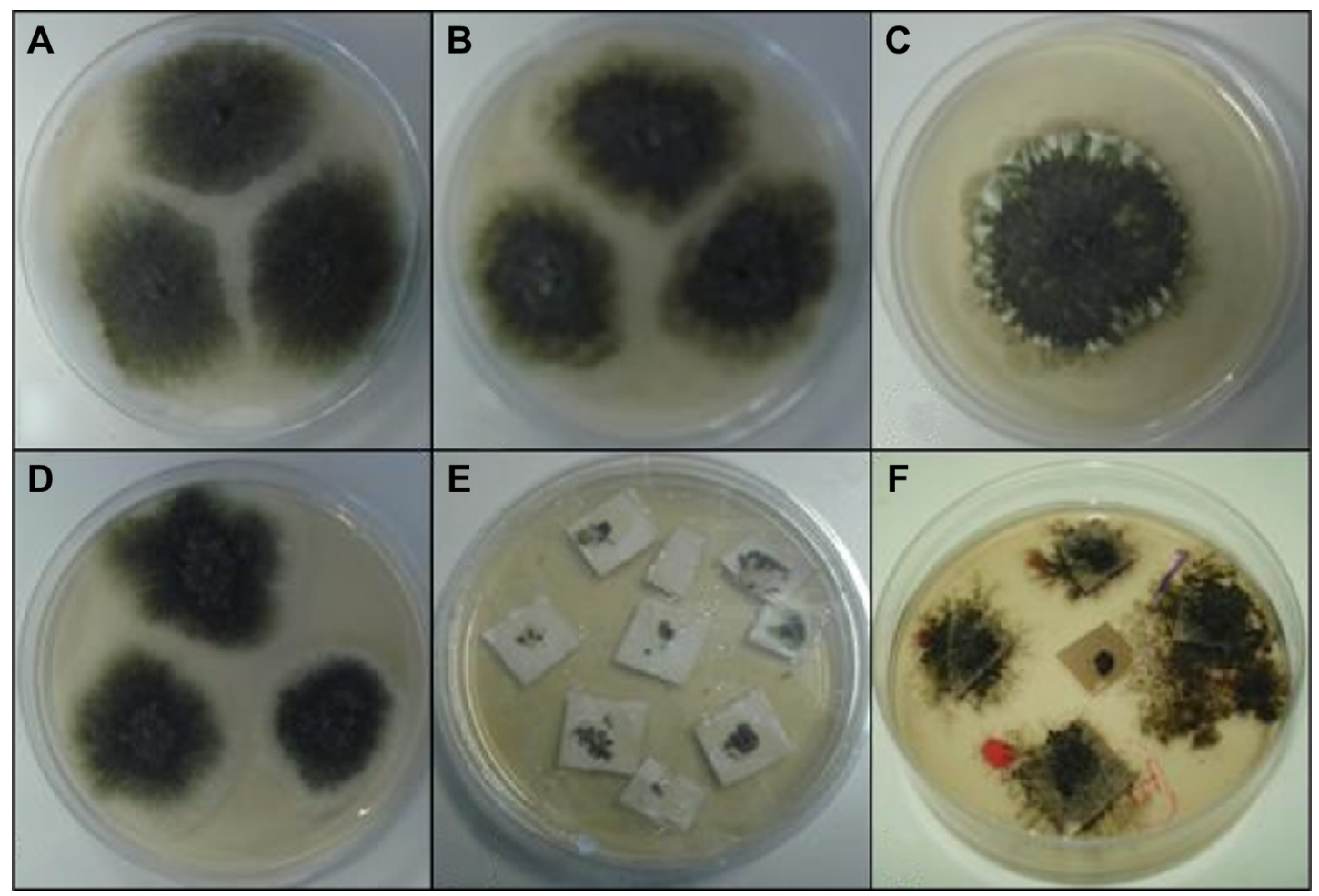

Fig 4 - Guignardia citricarpa colony aspect growing under different membrane types: (A) - filter paper; (B) - nylon; (C) cellulose ester; (D) - G. citricarpa wild type 12P; (E) - agrotransformation experiment, cocultivation step; (F) - growing of G. citricarpa transformants hygromycin B resistant. No morphological differences of any of cultivation variants between transformants and wild type 12P.

with $200 \mu \mathrm{M} \mathrm{mL}^{-1}$ AS and transferred to culture medium for selection and growth for $60 \mathrm{~d}$ at $28^{\circ} \mathrm{C}$ (Table 1). Under these conditions, in three independent experiments, the number of hygromycin-resistant transformant colonies per experiment ranged from 42 to 86 , resulting in a total of 175 hygromycin B resistant transformants expressing gfp, which were picked and stored in a library with 144 transformants for future studies, especially for pathogenicity.

The establishment of the Agrobacterium transformation system for $G$. citricarpa enables the generation of transformants and use of this tool for studies of insertional mutagenesis and gene disruption in order to identify important genes, such as those involved in the pathogenic mechanisms used by this fungus.

Different membranes such as nitrocellulose, nylon (Hybond), cellophane, and tissue paper have been used in the step of cocultivation for different protocols. In general, membranes of nitrocellulose and Hybond $C$ have provided lower efficiencies of transformation (Vijn \& Govers 2003; Michielse et al. 2005) than filter paper and Hybond $\mathrm{N}^{+}$(Zeilinger 2004). Fávaro (2009) observed that significant increases in the number of resistant colonies were obtained when nylon membranes

\section{PECTINASE}

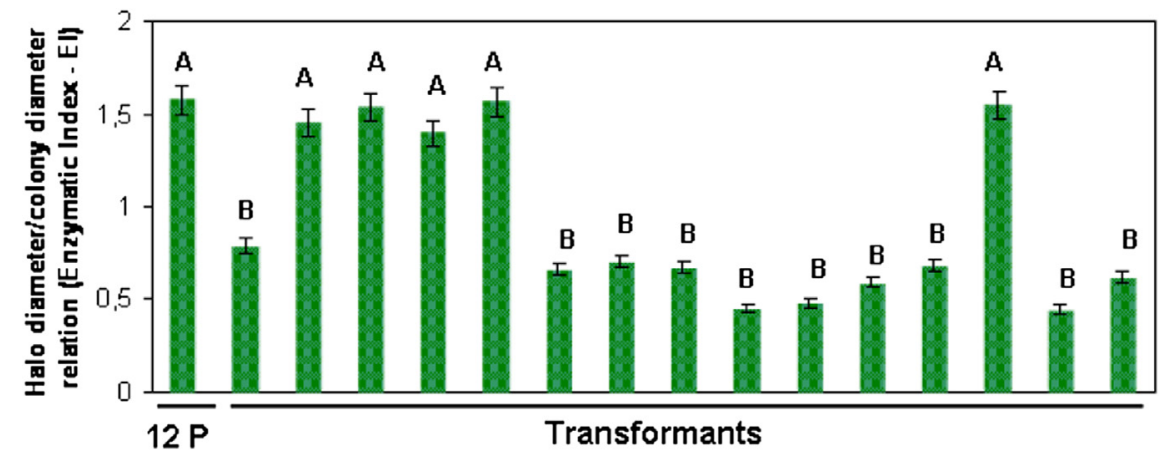

Fig 5 - Pectinase production profile by Guignardia citricarpa transformants. Mean values, with three replicates. Means followed by same letter do not differ by Tukey test (alpha $=0.05$ ). 

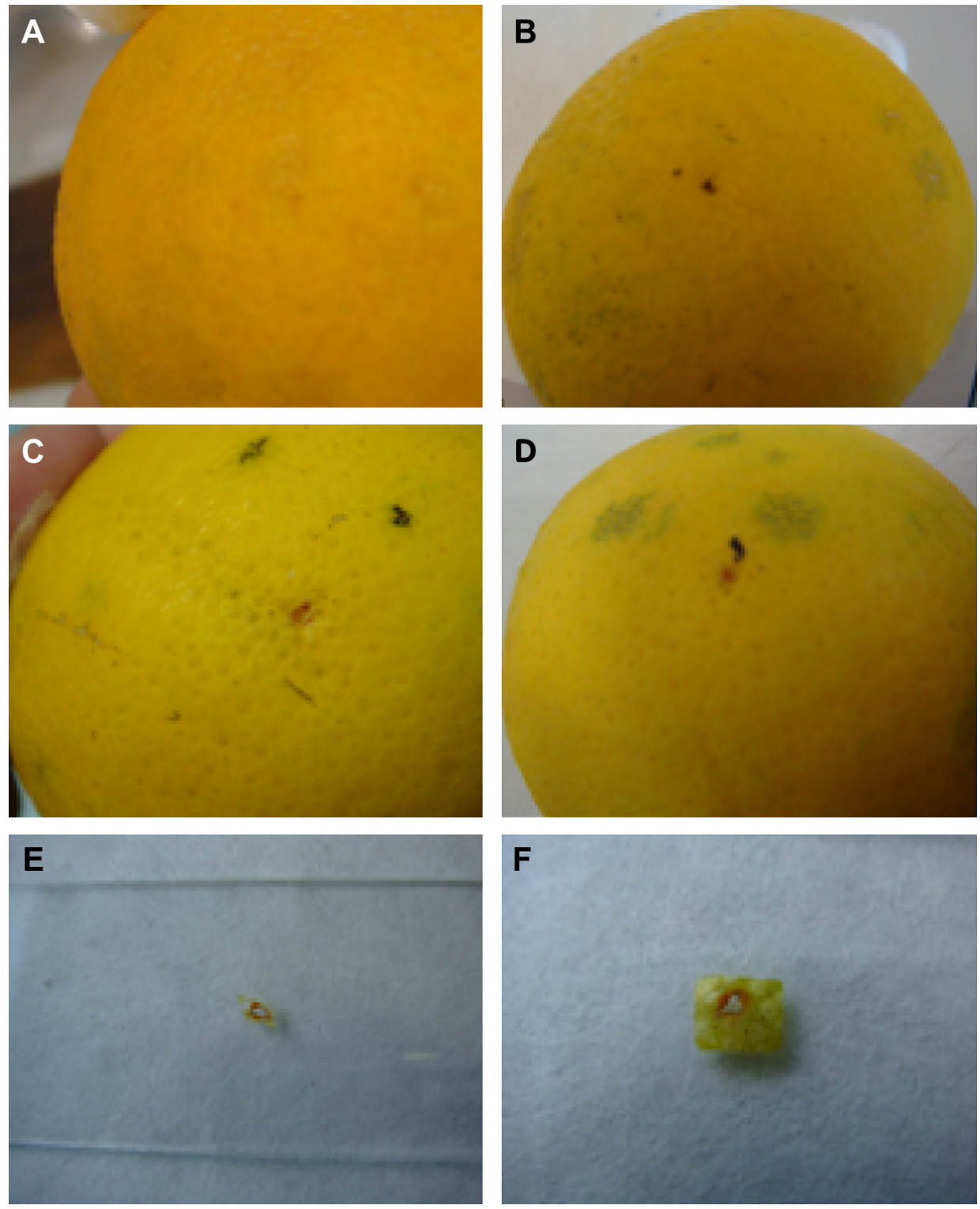

Fig 6 - Pathogenicity bioassay showing the ability of Guignardia citricarpa transformants to produce typical symptoms of CBS disease. Citrus inoculated with G. citricarpa. (A) Negative control, only wound the bark, (B) negative control, wound inoculated with spores of the endophytic species G. mangiferae, showing no symptoms developed, as expected, (C) positive control, spores of pathogenic specie G. citricarpa strain resulting in formation of the characteristic symptom of CBS disease, (D) characteristic symptom of the disease, caused G. citricarpa transformants, and (E, F) characteristic symptom of the disease, caused by inoculation of spores of G. citricarpa transformants. Observation in epifluorescence microscopy, cuts under sterile blades. (For interpretation of the references to colour in this figure legend, the reader is referred to the web version of this article.)

were used in coculture. The same was also reported for Aspergillus fumigatus (Sugui et al. 2005) and for the oomycete Phytophthora infestans (Vijn \& Govers 2003).

Changes in cocultivation time have also caused variation in the transformation efficiency. For most fungal species, cocultivation time during $48 \mathrm{~h}$ resulted in a higher transformation efficiency (De Groot et al. 1998; Mullins \& Kang 2001; Rho et al. 2001; Leal et al. 2004; Weld et al. 2006; Zhong et al. 2007), however, in some cases the extent of time can result in a greater number of transformants (Combier et al. 2003), as observed in this study (Table 1) and other fungi such as Fusarium oxysporum
(Mullins \& Kang 2001), Beauveria bassiana (Leclerque et al. 2004), Colletotrichum graminicola (Flowers \& Vaillancourt 2005), Colletotrichum falcatum, and Colletotrichum acutatum (Maruthachalam et al. 2008), Cryptococcus neoformans (McClelland et al. 2005), Magnaporthe oryzae (Betts et al. 2007), and Epicoccum nigrum (Fávaro 2009). G. citricarpa has a highly pigmented mycelial mass and a thick wall, factors that can hinder the transformation process, as was shown for Coniothyrium minitans (Rogers et al. 2004) and E. nigrum (Fávaro 2009).

Following this optimized protocol, a total of three experiments were conducted allowing the recovery of 175 

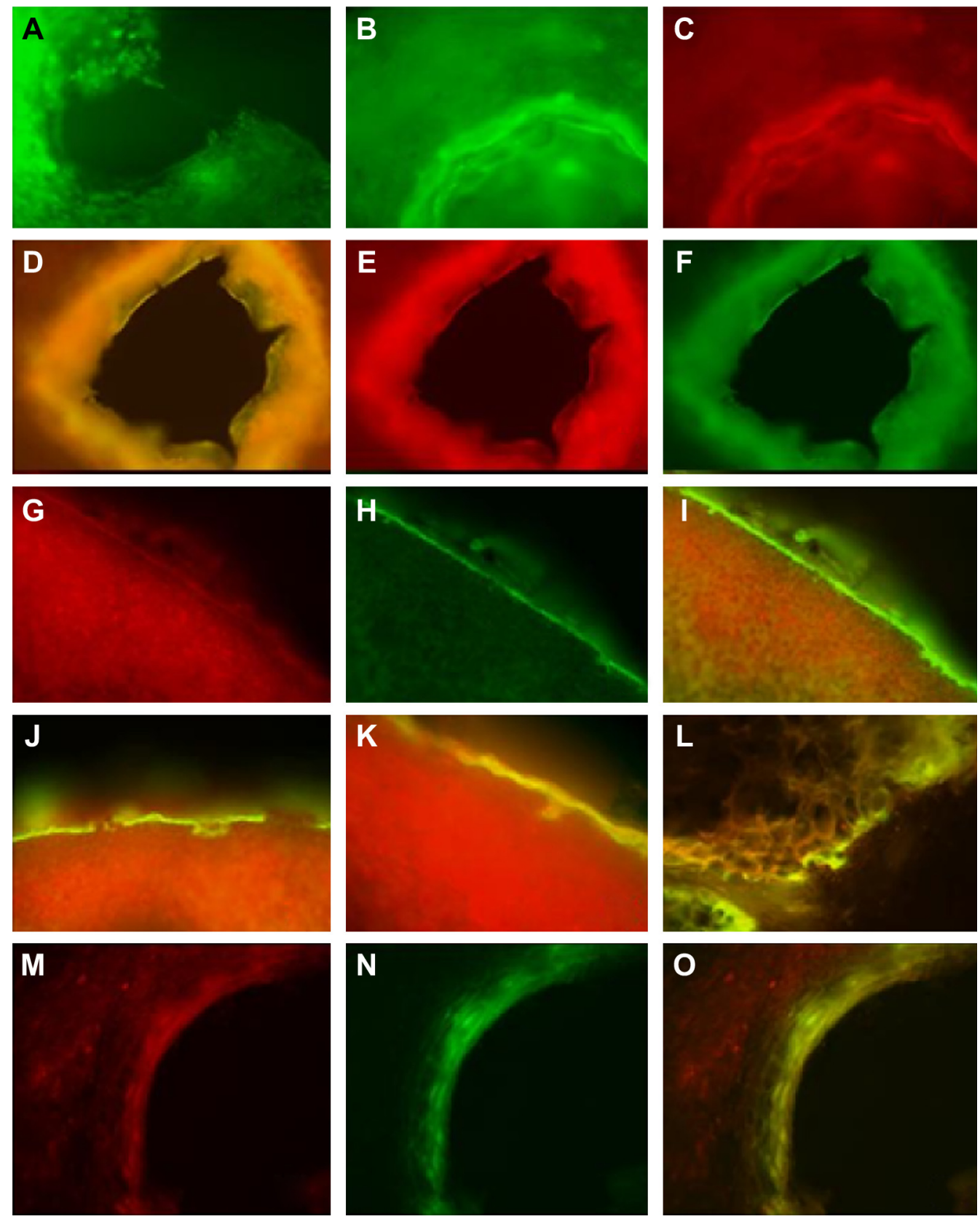

Fig 7 - Images of CBS symptoms caused by Guignardia citricarpa transformants under epifluorescence microscopy. The symptoms evaluated come from the fruit used in the pathogenicity test. $(A-C)$ Negative control, damage caused by Guignardia citricarpa wild type 12P. Note that no fluorescence under the FITC filter (A, B) was observed, only a slight fluorescence coming from the plant tissue, collected under the Rhodamine filter (C) $(100 \times)$, (D-F) negative control, fruit skin injury without infection of $G$. citricarpa transformants. Observe that there is no fluorescence being issued, even with the overlap of filters (D), FITC (F), and Rhodamine (E) (100x), (G-I) there is a mass of mycelium of a G. citricarpa transformant growing across the surface of plant tissue, emitting intense fluorescence $(200 \times),(J)$ initial colonization of the intercellular spaces of plant tissue $(200 \times)$ ), $(\mathrm{K})$ note the formation of a cellular penetration organ, as an appressorium or a haustorium $(200 \times)$, (L) detail of plant cells being enveloped by the transgenic fungi mycelial mass (100×); (M-O) details of the injury and colonization of the first layer of plant cells $(100 \times)$. (For interpretation of the references to colour in this figure legend, the reader is referred to the web version of this article.)

hygromycin B resistant transformants expressing gfp. Although for most of fungi, such as E. nigrum (Fávaro 2009) and Trichoderma virens (Romão 2010), the transformants were obtained after a short period of time (4-15 d), G. citricarpa transformants were obtained only after $60 \mathrm{~d}$. This is especially because $G$. citricarpa is a fungus that presents a slow growing, normally about $15 \mathrm{~d}$ in Petri dishes conditions. 
Moreover, the number of transformants also differs significantly from the results found in literature, for example, in Venturia inaequalis they have results of 223 transformants per $200 \mathrm{mg}$ of mycelium (Fitzerland et al. 2003) and Verticillium fungicola with 4.07 transformants per $10^{5}$ conidia (Amey et al. 2002).

This is also due to the fact that G. citricarpa Agrobacteriummediated transformants was used with mycelium as starting material for transformation. Other fungi with most voracious growth naturally sporulate under laboratory conditions. For this reason, we used mycelia to this study. Thus, spores or conidia can be used as starting material for transformation, which substantially increases the number of transformants generated. Generally, the increase in fungal cells leads to an increase in the number of transformants (Zwiers \& De Waard 2001; Rolland et al. 2003; Reis et al. 2004; Rogers et al. 2004; Zeilinger 2004). It was also observed by Mikosh et al. (2001), demonstrating that the use of germinated spores, instead of mycelium, led to increased formation of transformants containing multiple copies of T-DNA.

G. citricarpa transformants presented high mitotic stability (82\%). High mitotic rate stability has also been described for different fungal species transformed with $g f p$ gene by the Agrobacterium system (Fitzerland et al. 2003; Gorfer et al. 2007; Martino et al. 2007; Wang et al. 2008). There was also a high rate of sector formation in the transformants. The sector formation in G. citricarpa may be related to loss of RNAdf (Kava-Cordeiro et al. 2008).

Randomly selected transformants were analysed by epifluorescence microscopy (MOF) (Fig 3). The fluorescence emission was observed in the hyphae of all transformants evaluated, showing the stability of these transformants, resulted from stable mRNA synthesis and its translation. As expected, hyphae of wild type 12P G. citricarpa fluorescence were not detected. The expression of gfp in the transformants was distributed throughout the hyphae, which can be noted in some segments of hyphae with reduced expression or no expression of gfp (Fig 3). In Leptosphaeria maculans (Eckert et al. 2005), this pattern of gfp expression was reported, where the light microscopic analysis of the hyphae segments without expression revealed that these regions had collapsed cells in older hyphae. The non-uniform distribution of fluorescence in hyphae of some fungal species has been related to the exclusion of gfp vacuoles and mitochondria along with abundant accumulation of this protein in the nuclei and cytoplasm (Fernández-Ábalos et al. 1998).

In the results of this work, even a transgenic strain showing less production of pectinase, an important enzyme in pathogenicity systems (Jones et al. 1972; Isshiki et al. 2001), this lower production by itself was not sufficient to decrease the ability of this transformant to cause the CBS symptoms in fruits.

The different steps involved in differentiation and development of plant pathogens in the environment are still poorly known, showing more study is needed to assess the plant-fungus interaction.

The ATMT method is very attractive to obtain phenotypes mutants and identify genes related to these via random insertional mutagenesis. Responsive gene related to the pathogenic character of fungi species, could be identified or knocked out by this technique, allowing the study of several pathogenic systems (Rho et al. 2001; Combier et al. 2003; Leclerque et al. 2004; Rogers et al. 2004; Walton et al. 2005; White \& Chen 2007; Zhong et al. 2007; Talhinhas et al. 2008). The establishment of this methodology for $G$. citricarpa future experiments can be efficiently performed in order to achieve similar results.

Overall, the results showed that the transformed fungus intensely colonizes the fruit surface, forming a dense mycelial mass around the epidermal cells. This is the first time that results using gfp were observed in G. citricarpa. Furthermore, the analysis of cross sections also revealed that $G$. citricarpa is able to penetrate the host tissue and colonize the intercellular space of the first layers of fruit peel epidermis. In this way, we can infer that the genetic transformation did not affect this ability to cause injury, i.e., as the insertion of exogenous DNA is random in the fungus genome, occurred at loci that have no effect on the capability of this fungus to develop disease symptoms.

\section{Acknowledgements}

We are grateful to Prof. Dr Carlos Alberto Labate (USP-ESALQ, Brazil) for provision of Agrobacterium tumefaciens EAH105 and to Dr M. Kim Plummer (CSIRO Plant Industry, Australia) for kindly providing the pFAT-gfp plasmid. Thanks to Dr David H. Moon for suggestions. This work was supported by grant from the Fundo Paulista de Defesa da Citricultura (FUNDECITRUS) and grant from Conselho Nacional de Pesquisa (CNPq) to MBCR.

\section{R E F E R E N C E S}

Abdudeh RO, Orbach MJ, Mandel MA, Das A, Galgiani JN, 2000. Genetic transformation of Coccidioides immitis facilitated by Agrobacterium tumefaciens. The Journal of Infectious Disease 181: 2106-2110.

Adaskaveg J, Korsten L, Agostini JP, Levy L, Bulluck R, Miles A, Carroll G, Palm M, Dewdnwy M, Peres N, Eel-Lissy O, Schubert T, Gottwald T, Seaver D, Henderson M, Spósito MB, Hollingsworth C, Timmer P, Hornby P, Zeller K, Hornyak M, 2 Jun. 2010. Guignardia citricarpa (Citrus Black Spot, CBS) Technical Working Group Final Report. United States Department of Agriculture (USDA), Animal Plant Health Inspection Service (APHIS), Plant Protection and Quarantine (PPQ), Center for Plant Health Science and Technology (CPHST), Washington.

Amey RC, Athey-Pollard A, Burns C, Mills PR, Bailey A, Foster GD, 2002. PEG-mediated and Agrobacterium-mediated transformation in the mycopathogen Verticillium fungicola. Mycological Research 106: 4-11.

Betts MF, Tucker SL, Galadima N, Meng Y, Patel G, Li L, Donofrio N, Floyd A, Nolin S, Brown D, Mandel MA, Mitchell TK, Xu JR, Dean RA, Farman ML, Orbach MJ, 2007. Development of a high throughput transformation system for insertional mutagenesis in Magnaporthe oryzae. Fungal Genetics and Biology 44: 1035-1049.

Blaise F, Remy E, Meyer M, Zhou L, Narcy JP, Roux J, Balesdent MH, Rouxel T, 2007. A critical assessment of Agrobacterium tumefaciens-mediated transformation as a tool for pathogenicity gene discovery in the phytopathogenic fungus Leptosphaeria maculans. Fungal Genetics and Biology 44: 123-138. 
Bonants PJM, Carroll GC, Weerdt M, van Brouwershaven IR, Baayen RP, 2003. Development and validation of a fast PCRbased detection method for pathogenic isolates of the citrus black spot fungus, Guignardia citricarpa. European Journal of Plant Pathology 109: 503-513.

Castellani A, 1963. The "water cultivation" of pathogenic fungi. Journal of Tropical Medicine \& Hygiene 66: 283-284.

Chilton M, Currier TC, Farrand SK, Bendicht AJ, Gordon MP, Nester EW, 1974. Agrobacterium tumefaciens DNA and PS8 bacteriophage DNA not detected in crown gall tumors. Proceedings of the National Academy of Sciences 71: 3672-3676.

Combier JP, Melayah D, Raffier C, Gay G, Marmeisse R, 2003. Agrobacterium tumefaciens-mediated transformation as a tool for insertional mutagenesis in the symbiotic ectomycorrhizal fungus Hebeloma cylindrosporum. FEMS Microbiology Letters 220: 141-148.

Eckert M, Maguire K, Urban M, Foster S, Fitt B, Lucas J, HammondKosack K, 2005. Agrobacterium tumefaciens-mediated transformation of Leptosphaeria spp. and Oculimacula spp. with the reef coral gene DsRed and the jellyfish gene gfp. FEMS Microbiology Letters 253: 67-74.

European and Mediterranean Plant Protection Organization, 2006. Fungicide resistance: definitions and use of terms. Bulletin OEPP/EPPO Bulletin 18: 569-571.

Fávaro LCL, 2009. Diversidade e interação de Epicoccum spp. com cana-de-açúcar (Saccharum officinarum, L.) Tese (Doutorado em Genética e Melhoramento de Plantas). Escola Superior de Agricultura "Luiz de Queiroz", Universidade de São Paulo, Piracicaba, Brazil 219.

Fernández-Ábalos JM, Fox H, Pitt C, Wells B, Doonan JH, 1998. Plant-adapted green fluorescent protein is a versatile vital reporter for gene expression, protein localization and mitosis in the filamentous fungus, Aspergillus nidulans. Molecular Microbiology 27: 121-130.

Figueiredo JG, Goulin EH, Tanaka F, Stringari D, Kava-Cordeiro V, Galli-Terasawa LV, Staats CC, Schrankand A, Glienke C, 2010. Agrobacterium tumefaciens-mediated transformation of Guignardia citricarpa. Journal of Microbiological Methods 80: 143-147.

Fitzerland AM, Mudge AM, Gleave AP, Plummer KM, 2003. Agrobacterium and PEG-mediated transformation of the phytopathogen Venturia inaequalis. Mycological Research 107: 803-810.

Flowers JL, Vaillancourt LJ, 2005. Parameters affecting the efficiency of Agrobacterium tumefaciens-mediated transformation of Colletotrichum graminicola. Current Genetics 48: 380-388.

Gorfer M, Klaubauf S, Bandian D, Strauss J, 2007. Cadophora finlandia and Phialocephala fortinii: Agrobacterium-mediated transformation and functional GFP expression. Mycological Research 111: 850-855.

De Groot MJ, Bundok P, Hooykaas PJ, Beijersbergen AG, 1998. Agrobacterium tumefaciens-mediated transformation of filamentous fungi. Nature Biotechnology 16: 839-842.

Hankin L, Anagnostakis SG, 1975. The use of solid media for detection of enzyme production by fungi. Mycologia 67: 597-607.

Isshiki A, Akimitsu K, Yamamoto M, Yamamoto H, 2001. Endopolygalacturonase is essential for citrus black rot caused by Alternaria citri but not brown spot caused by Alternaria alternata. Molecular Plant-Microbe Interactions 14: 749-757.

Jones TM, Anderson AJ, Albersheim P, 1972. Host pathogen interactions studies on the polysaccharide degrading enzymes secreted by Fusarium oxysporum f. sp. lycopersici. Physiological Plant Pathology 2: 153-166.

Kava-Cordeiro V, Nishimura RC, Mariussi RC, Montenegro DH, Stringari D, Fabris J, Silvano C, Galli-Terasawa LV, Glienke C, Azevedo JL, 2008. Ocorrência de RNA dupla fita em Guignardia citricarpa e G. mangiferae: relações com a patogenicidade e especificidade com o hospedeiro. In: Congresso Brasileiro de Genética 54 Anais, p. 35.
Kotzé JM, 1981. Epidemiology and control of citrus black spot in South Africa. Plant Disease 65: 945-950.

Kotzé JM, 2000. Black spot. In: Timmer LW, Garnsey SM, Graham JH (eds), Compendium of Citrus Diseases. American Phytopathology Society, St. Paul, USA, pp. 23-25.

Lacorte C, Romano E, 1998. Transferência de vetores para Agrobacterium. In: Brasileiro ACM, Carneiro VT (eds), Manual de transformação genética de plantas. SPI/EMBRAPA, Brasília, pp. 93-109.

Lacroix B, Tzfira T, Vainstein A, Citovsky V, 2006. A case of promiscuity: Agrobacterium's endless hunt for new partners. Trends in Genetics 22: 29-37.

Leal CV, Montes BA, Mesa AC, Rua AL, Corredor M, Restrepo A, McEwen JG, 2004. Agrobacterium tumefaciens-mediated transformation of Paracoccidioides brasiliensis. Medical Mycology 42: 391-395.

Leclerque A, Wan H, Abschutz A, Chen S, Mitina GV, Zimmermann G, Schairer HU, 2004. Agrobacterium-mediated insertional mutagenesis (AIM) of the entomopathogenic fungus Beauveria bassiana. Current Genetics 45: 111-119.

Liu YG, Whittier RF, 1995. Thermal asymmetric interlaced PCR: automatable amplification and sequencing of insert end fragments from P1 and YAC clones for chromosome walking. Genomics 25: 674-681.

Lorang JM, Tuori RP, Martinez JP, Sawyer TL, Redman RS, Rollins JA, Wolpert TJ, Johnson KB, Rodriguez RJ, Dickman MB, Ciuffetti LM, 2001. Green fluorescent protein is lighting up fungal biology. Applied and Environmental Microbiology 67: 1987-1994.

Martino E, Murat C, Vallino M, Bena A, Perotto S, Spanu P, 2007. Imaging mycorrhizal fungal transformants that express EGFP during ericoid endosymbiosis. Current Genetics 52: 65-75.

Maruthachalam K, Nair V, Rho HS, Choi J, Kim S, Lee YH, 2008. Agrobacterium tumefaciens-mediated transformation in Colletotrichum falcatum and C. acutatum. Journal of Microbiology and Biotechnology 18: 234-241.

McClelland CM, Chang YC, Kwon-Chung KJ, 2005. High frequency transformation of Cryptococcus neoformans and Cryptococcus gattii by Agrobacterium tumefaciens. Fungal Genetics and Biology 42: 904-913.

McOnie KC, 1965. Source of infection for black spot of citrus. The South African Citrus Journal 5-9.

Michielse C, Hooykaas P, Van den Hondel C, Ram A, 2005. Agrobacterium-mediated transformation as a tool for functional genomics in fungi. Current Genetics 48: 1-17.

Mikosh TS, Lavrijssen B, Sonnenberg AS, van Griensven LJ, 2001. Transformation of the cultivated mushroom Agaricus bisporus (Lange) using T-DNA from Agrobacterium tumefaciens. Current Genetics 39: 35-39.

Mullins ED, Kang S, 2001. Transformation: a tool for studying fungal pathogens of plants. Cellular and Molecular Life Sciences 58: 2043-2052.

Raeder U, Broda P, 1985. Rapid preparation of DNA from filamentous fungi. Letters in Applied Microbiology 1: 17-20.

Reis MC, Fungaro MHP, Duarte RTD, Furlaneto L, Furlaneto MC, 2004. Agrobacterium tumefaciens-mediated genetic transformation of the entomopathogenic fungus Beauveria bassiana. Journal of Microbiological Methods 58: 197-202.

Rho HS, Kang S, Lee YH, 2001. Agrobacterium tumefaciens mediated transformation of the plant pathogenic fungus, Magnaporthe grisea. Molecular Cell 12: 407-411.

Rodrigues MBC, Spósito MB, Aguilar-Vildoso CI, Andreote FD, Araújo WL, Pizzirani-Kleiner AA, 2007. Resistência a Benzimidazóis por Guignardia citricarpa, agente causal da Mancha Preta dos Citros. Pesquisa Agropecuária Brasileira 3: 323-327.

Rogers CW, Challen MP, Green JR, Whipps JM, 2004. Use of REMI and Agrobacterium-mediated transformation to identify 
pathogenicity mutants of the biocontrol fungus, Coniothyrium minitans. FEMS Microbiology Letters 241: 207-214.

Rolland S, Jobic C, Fèvre M, Bruel C, 2003. Agrobacterium-mediated transformation of Botrytis cinerea, simple purification of monokaryotic transformants and rapid conidia-based identification of the transfer-DNA host genomic DNA flanking sequences. Current Genetics 44: 164-171.

Romão AS, 2010. Análise da comunidade fúngica associada à cana-de-açúcar e estudo da interação Trichoderma virens planta hospedeira Tese (Doutorado em Genética e Melhoramento de Plantas). Escola Superior de Agricultura "Luiz de Queiroz", Universidade de São Paulo, Piracicaba, Brazil 270.

Sambrook J, Russell DW, 2001. Molecular Cloning: A Laboratory Manual, 3rd edn. Cold Spring Harbor Laboratory Press, Cold Spring Harbor, NY.

Schubert T, Sutton B, Jeyaprakash A, 5 Apr. 2010. Citrus Black Spot (Guignardia citricarpa) discovered in Florida. In: Pest Alert. Florida Department of Agriculture and Consumer Services, Division of Plant Industry, Charles H. Bronson, Commissioner of Agriculture, Florida.

Smith MC, 2006. Passenger Processing: Citrus black spot. Phyllosticta citricarpa, intercepted on oranges from Cuba. USDA-APHIS-PPQ Report of a Significant Agriculturao Inspection Incident at Miami Service Port, Cuba, n. 26.

Smith IM, McNamara DG, Scott PR, Holderness M, Burger B, 1997. Quarantine pests for Europe. In: Data Sheets on Quarantine Pests for the European Union and for the European and Mediterranean Plant Protection Organization, 2nd edn. CAB International, Wallingford, UK.

Snowdon AL, 1990. A colour atlas of post-harvest diseases and disorders of fruits and vegetables. In: General Introduction and Fruits. Wolfe Scientific Ltd., London, UK, pp. 62-63.
Sugui JA, Chang YC, Kwon-Chung KJ, 2005. Agrobacterium tumefaciens-mediated transformation of Aspergillus fumigatus: an efficient tool for insertional mutagenesis and targeted gene disruption. Applied and Environmental Microbiology 71: 1798-1802.

Talhinhas P, Muthumeenakshi S, Neves-Martins J, Oliveira H, Sreenivasaprasad S, 2008. Agrobacterium-mediated transformation and insertional mutagenesis in Colletotrichum acutatum for investigating varied pathogenicity lifestyles. Molecular Biotechnology 39: 57-67.

Vijn I, Govers F, 2003. Agrobacterium tumefaciens mediated transformation of the oomycete plant pathogen Phytophthora infestans. Molecular Plant Pathology 4: 459-467.

Walton FJ, Idnurm A, Heitman J, 2005. Novel functions required for melanization of the human pathogen Cryptococcus neoformans. Molecular Microbiology 57: 1381-1386.

Wang J, Guo L, Zhang K, Wua Q, Lin J, 2008. Highly efficient Agrobacterium-mediated transformation of Volvariella volvacea. Bioresource Technology 99: 8524-8527.

Weld RJ, Eady CC, Ridgway HJ, 2006. Agrobacterium-mediated transformation of Sclerotinia sclerotiorum. Journal of Microbiological Methods 65: 202-207.

White D, Chen W, 2007. Towards identifying pathogenic determinants of the chickpea pathogen Ascochyta rabiei. European Journal of Plant Pathology 119: 3-12.

Zeilinger S, 2004. Gene disruption in Trichoderma atroviride via Agrobacterium-mediated transformation. Current Genetics 45: 54-60.

Zhong Y, Liu S, Che Y, Liu X, 2007. Epicoccins A-D, epipolythiodioxopiperazines from a Cordyceps-colonizing isolate of Epicoccum nigrum. Journal of Natural Products 70: 1522-1525.

Zwiers LH, De Waard MA, 2001. Efficient Agrobacterium tumefaciens-mediated gene disruption in the phytopathogen Mycosphaerella graminicola. Current Genetics 39: 388-393. 